\title{
Prenatal Nicotine Exposure Alters the Responses to Subsequent Nicotine Administration and Withdrawal in Adolescence: Serotonin Receptors and Cell Signaling
}

\author{
Theodore A Slotkin*,', Charlotte A Tate', Mandy M Cousins' and Frederic J Seidler' \\ 'Department of Pharmacology and Cancer Biology, Duke University Medical Center, Durham, NC, USA
}

\begin{abstract}
Offspring of women who smoke during pregnancy are themselves more likely to take up smoking in adolescence, effects that are associated with a high rate of depression and increased sensitivity to withdrawal symptoms. To evaluate the biological basis for this relationship, we assessed effects on serotonin (5-hydroxytryptamine, $5 \mathrm{HT}$ ) receptors and $5 \mathrm{HT}$-mediated cellular responses in rats exposed to nicotine throughout prenatal development and then given nicotine in adolescence (postnatal days PN30-47.5), using regimens that reproduce plasma nicotine levels found in smokers. Evaluations were then made during the period of adolescent nicotine treatment and for up to one month after the end of treatment. Prenatal nicotine exposure, which elicits damage to $5 \mathrm{HT}$ projections in the cerebral cortex and striatum, produced sex-selective changes in the expression of $5 \mathrm{HT}_{\mathrm{IA}}$ and $5 \mathrm{HT}_{2}$ receptors, along with induction of adenylyl cyclase (AC), leading to sensitization of heterologous inputs operating through this signaling pathway. Superimposed on these effects, the AC response to $5 \mathrm{HT}$ was shifted toward inhibition. By itself, adolescent nicotine administration, which damages the same pathways, produced similar effects on receptors and the $5 \mathrm{HT}$-mediated response, but a smaller overall induction of AC. Animals exposed to prenatal nicotine showed a reduced response to nicotine administered in adolescence, results in keeping with earlier findings of persistent desensitization. Our results indicate that prenatal nicotine exposure alters parameters of $5 \mathrm{HT}$ synaptic communication lasting into adolescence and changes the response to nicotine administration and withdrawal in adolescence, actions which may contribute to a subpopulation especially vulnerable to nicotine dependence.
\end{abstract}

Neuropsychopharmacology (2006) 31, 2462-2475. doi: I 0.I 038/sj.npp. I 300988; published online 7 December 2005

Keywords: adenylyl cyclase; adolescence; brain development; nicotine; serotonin receptors

\section{INTRODUCTION}

Cigarette smoking typically begins in adolescence (Nelson et al, 1995; Pierce and Gilpin, 1996), and the earlier the onset, the greater the eventual daily consumption and the lower the probability of quitting (Chassin et al, 1996; Chen and Millar, 1998). Animal models of nicotine administration confirm that there is a biological basis for the greater susceptibility of adolescents to nicotine dependence and addiction, including greater and more persistent nicotinic acetylcholine receptor (nAChR) upregulation than in adults, outright neuronal loss in brain regions responsible for learning, memory and mood, and more pronounced alterations in synaptic activity upon withdrawal of nicotine (Abreu-Villaça et al, 2003a-c; Slotkin, 2002; Trauth et al,

*Correspondence: Dr TA Slotkin, Box 3813 DUMC, Duke University Medical Center, Durham, NC 277I0, USA, Tel: + I 91968 I 80I5, Fax: + I9196848197, E-mail: t.slotkin@duke.edu

Received 16 August 2005; revised 12 October 2005; accepted 13 October 2005

Online publication: 27 October 2005 at http://www.acnp.org/citations/ Npp 1027050505 | 8/default.pdf
1999, 2000a, 2001). These differences from nicotine effects in adults also carry over to behavioral outcomes (Adriani et al, 2002, 2003; Faraday et al, 2001, 2003; Levin, 1999; Trauth et al, 2000c).

Superimposed on the greater susceptibility of adolescents to nicotine dependence and addiction, there are subpopulations that are especially vulnerable, most notably those whose mothers smoked during pregnancy (Cornelius et al, 2000; Kandel et al, 1994; Niaura et al, 2001). Fetal nicotine exposure elicits neural cell death, alters cell proliferation and differentiation, and evokes lasting deficits in synaptic function and behavioral performance (reviews, Levin and Slotkin, 1998; Slotkin, 1992, 1998, 1999, 2004). Indeed, recent work has pointed toward persistent changes in the subsequent response to nicotine after prenatal nicotine exposure, findings that again point to biological mechanisms underlying differential susceptibilities in the adolescent. Rats given fetal nicotine exposures mimicking those in heavy maternal smoking display cholinergic hypoactivity that emerges at adolescence (Zahalka et al, 1992), accompanied by deficiencies of cholinergic responses mediated through nAChRs (Abreu-Villaça et al, 2004b; Seidler et al, 
1992) and further neuronal loss (Abreu-Villaça et al, 2004a); reinforcing the synaptic and neurochemical alterations, prenatal nicotine exposure also influences nicotine selfadministration in adolescence (Klein et al, 2003).

The current study pursues the specific role of serotonin (5-hydroxytryptamine, 5HT) and some of its related cell signaling mechanisms in the interaction between prenatal nicotine exposure and the response to nicotine administration and withdrawal in the adolescent. Adolescent smokers have a high rate of depression (Goodman and Capitman, 2000; Martini et al, 2002; Patten et al, 2000; Wu and Anthony, 1999), and abnormalities of 5HT function are generally accepted to underlie the etiology and therapeutics of major depression (Maes and Meltzer, 1995). Depression is worsened by nicotine withdrawal, a major factor in failed attempts at smoking cessation (Colby et al, 2000; Salin-Pascual et al, 1995; Tsoh et al, 2000); again, this is a greater problem in adolescent smokers (Colby et al, 2000; Hurt et al, 2000). It is thus notable that nicotine administration to adolescent rats produces profound suppression of 5HT presynaptic activity upon cessation of nicotine administration, in conjunction with alterations in the ability of 5HT receptors to mediate cell signals in their target regions (Xu et al, 2001, 2002). Furthermore, prenatal nicotine exposure damages the same 5HT projections (Xu et al, 2001). Accordingly, in the present work, we carried out longitudinal evaluations of nicotine administration in adolescence and for up to 1 month after withdrawal of nicotine, comparing the effects in animals with or without prior exposure to prenatal nicotine. We assessed two $5 \mathrm{HT}$ receptor subtypes, $5 \mathrm{HT}_{1 \mathrm{~A}}$ and $5 \mathrm{HT}_{2}$, that are known to be affected in human depression (Arango et al, 2001; Fujita et al, 2000; Yatham et al, 1999, 2000). In addition, we evaluated cellular responses mediated through adenylyl cyclase (AC), a signaling pathway that plays critical roles in both dependence and withdrawal (Abreu-Villaça et al, 2003b; Nestler, 1992; Tzavara et al, 2002), and that we previously found to be affected by adolescent nicotine administration and abstinence (AbreuVillaça et al, 2003b; Xu et al, 2002). Effects on AC responses can be mediated either through 'heterologous' mechanisms, where changes occur in the level or activity of AC itself, influencing the responses to all receptors that converge on cyclic AMP, or through 'homologous' mechanisms involving changes in response to a specific receptor. We assessed both alternatives. First, we measured basal $\mathrm{AC}$ and the response to two direct stimulants (forskolin, $\mathrm{Mn}^{2+}$ ) that bypass neurotransmitter receptors and that distinguish between AC isoforms (Slotkin et al, 2003; Zeiders et al, 1999). Second, we determined the AC response to 5HT input. The two 5HT receptor subtypes converge on AC through both stimulatory and inhibitory mechanisms (Barnes and Sharp, 1999; Duncan et al, 1999; Morin et al, 1992; Raymond et al, 1999; Rovescalli et al, 1993), so we evaluated the net balance of the AC response to 5HT itself, focusing on the shift from stimulatory to inhibitory responses noted previously for adolescent nicotine withdrawal (Xu et al, 2002). Determinations were made in brain regions comprising major 5HT terminal fields (cerebral cortex, striatum) as well as the brainstem, which contains the majority of 5HT cell bodies, and were contrasted with the cerebellum, a region sparse in cholinergic projections and that should therefore respond to nicotine only indirectly, through multisynaptic pathways.

\section{METHODS}

\section{Animals and Nicotine Infusions}

All studies were carried out with the approval of the Duke University Institutional Animal Care and Use Committee, in accordance with the declaration of Helsinki and with the Guide for the Care and Use of Laboratory Animals as adopted and promulgated by the National Institutes of Health. Timed-pregnant Sprague-Dawley rats were shipped on gestational day (GD) 2 by climate-controlled truck (total transit time $<1 \mathrm{~h}$ ), housed individually and allowed free access to food and water. There were four treatment groups: controls (prenatal vehicle + adolescent vehicle), prenatal nicotine exposure (prenatal nicotine + adolescent vehicle), adolescent nicotine exposure (prenatal vehicle + adolescent nicotine), and those receiving the combined treatment (prenatal nicotine + adolescent nicotine). On GD4, before implantation of the embryo in the uterine wall, each animal was quickly anesthetized with ether, a $3 \times 3 \mathrm{~cm}$ area on the back was shaved, and an incision made to permit s.c. insertion of type 2ML2 Alzet osmotic minipumps; ether is the preferred anesthetic for these types of studies because isoflurane and other halogenated anesthetics can damage the developing brain (Jevtovic-Todorovic et al, 2003; Levin et al, 1991), whereas ether does not (Slotkin et al, 1987). Pumps were prepared with nicotine bitartrate dissolved in bacteriostatic water to deliver an initial dose rate of $6 \mathrm{mg} / \mathrm{kg}$ of nicotine (calculated as free base) per day. The incision was closed with wound clips and the animals were permitted to recover in their home cages. Control animals were implanted with minipumps containing only the water and an equivalent concentration of sodium bitartrate, adjusted to the same $\mathrm{pH}(6.0)$ as the nicotine bitartrate solution. It should be noted that the pump, marketed as a 2-week infusion device, actually takes 17.5 days to be exhausted completely (information supplied by the manufacturer) and thus the nicotine infusion terminates during GD21. Maternal plasma nicotine levels achieved with this administration model resemble those seen in heavy smokers $(25-60 \mathrm{ng} / \mathrm{ml})$ as characterized previously (Isaac and Rand, 1972; Levin and Slotkin, 1998; Lichtensteiger et al, 1988; Murrin et al, 1985; Slotkin, 1992, 1998, 1999, 2004). This animal model also resembles the effects of maternal smoking in that fetal nicotine levels exceed those found in maternal plasma (Luck et al, 1985; Sarasin et al, 2003).

Parturition occurred during GD22, which was also taken as postnatal day (PN)0. After birth, pups were randomized within treatment groups and litter sizes were culled to 10 (five males and five females) to ensure standard nutrition. Randomization was repeated every few days to distribute differential effects of maternal caretaking equally among all litters; crossfostering, by itself, has no impact on neurochemical or behavioral effects of nicotine exposure (Ribary and Lichtensteiger, 1989). Animals were weaned on PN21.

On PN30, each animal was implanted with a minipump (Alzet type 1002) as already described, again set to deliver either vehicle or nicotine at an initial dose rate of 
$6 \mathrm{mg} / \mathrm{kg} /$ day, with the infusion terminating during PN47 (Slotkin, 1998; Trauth et al, 1999, 2000b). The nicotine exposure period thus spans the recognized boundaries of adolescence in the rat, as typified by endocrine, pubertal, and behavioral parameters (Spear, 2000). In the adolescent rat, this paradigm produces plasma nicotine levels of $25 \mathrm{ng} / \mathrm{ml}$, similar to that in typical smokers (Lichtensteiger et al, 1988; Trauth et al, 2000b). Studies were conducted at four time points, one during adolescent nicotine administration (PN45) and three during the post-treatment period (PN50, PN60, and PN75). Animals were decapitated and the cerebral cortex, striatum, brainstem, and cerebellum were dissected (Trauth et al, $2000 \mathrm{~b})$, frozen in liquid nitrogen, and stored at $-45^{\circ} \mathrm{C}$ until assayed. For each treatment group, 12 animals were examined at each age point, equally divided into males and females, with each litter of origin contributing no more than one male and one female to any of the adolescent treatment groups.

In a supplemental experiment to delineate the immediate effects of prenatal nicotine exposure on early development of $5 \mathrm{HT}_{1 \mathrm{~A}}$ receptors, pregnant rats received vehicle or nicotine as already described and fetuses were removed on GD18. Additional animals were allowed to deliver normally and pups taken on PN4. A cut was made rostral to the thalamus to separate the forebrain from the brainstem and the tissues were then frozen as already described. For the GD18 determinations, only one fetus was selected from each of 10 dams per treatment group and sex was not determined; for the PN4 study, one male and one female were selected from each of four litters per treatment group.

\section{Tissue Preparation and Assays}

All of the assay methodologies used in this study have appeared in previous papers (Aldridge et al, 2003; Meyer et al, 2003, 2004a, b), so only brief descriptions will be provided here. Tissues were thawed and homogenized (Polytron, Brinkmann Instruments, Westbury, NY, USA) in ice-cold $50 \mathrm{mM}$ Tris ( $\mathrm{pH} 7.4$ ), and the homogenates were sedimented at $40000 \mathrm{~g}$ for $15 \mathrm{~min}$. The pellets were washed by resuspension (Polytron) in homogenization buffer followed by resedimentation, and were then dispersed with a homogenizer (smooth glass fitted with Teflon pestle) in the same buffer. An aliquot was assayed for measurement of membrane protein (Smith et al, 1985).

Two radioligands were used to determine $5 \mathrm{HT}$ receptor binding (Xu et al, 2002): $1 \mathrm{nM}\left[{ }^{3} \mathrm{H}\right] 8$-hydroxy-2-(di- $n$ propylamino)tetralin (specific activity, $135 \mathrm{Ci} / \mathrm{mmol}$ ) for $5 \mathrm{HT}_{1 \mathrm{~A}}$ receptors (Park et al, 1999; Stockmeier et al, 1998), and $0.4 \mathrm{nM}\left[{ }^{3} \mathrm{H}\right]$ ketanserin (specific activity, $63 \mathrm{Ci} / \mathrm{mmol}$ ) for $5 \mathrm{HT}_{2}$ receptors (Leysen et al, 1982; Park et al, 1999). For $5 \mathrm{HT}_{1 \mathrm{~A}}$ receptors, incubations lasted for $30 \mathrm{~min}$ at $25^{\circ} \mathrm{C}$ in a

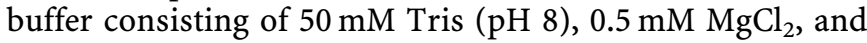
$0.5 \mathrm{mM}$ sodium ascorbate; $100 \mu \mathrm{M} 5 \mathrm{HT}$ was used to displace specific binding. For $5 \mathrm{HT}_{2}$ receptors, incubations lasted $15 \mathrm{~min}$ at $37^{\circ} \mathrm{C}$ in $50 \mathrm{mM}$ Tris ( $\mathrm{pH} \mathrm{7.4)}$ ) and specific binding was displaced with $10 \mu \mathrm{M}$ methylsergide. Incubations were stopped by the addition of excess of ice-cold incubation buffer (without radioligand or displacing agent) and the labeled membranes were trapped by rapid vacuum filtration onto glass fiber filters that were presoaked in $0.15 \%$ polyethyleneimine. The filters were then washed twice with $3 \mathrm{ml}$ of incubation buffer and radiolabel was determined. Since the cerebellum is sparse in 5HT terminals but enriched in noradrenergic projections, we assessed $\beta$ adrenoceptor $(\beta \mathrm{AR})$ binding instead of $5 \mathrm{HT}$ receptors, using $67 \mathrm{pM}\left[{ }^{125} \mathrm{I}\right]$ iodopindolol (specific activity, $2200 \mathrm{Ci}$ / $\mathrm{mmol}$ ) as the radioligand, with nonspecific binding assessed by displacement with $100 \mu \mathrm{M}$ isoproterenol.

$\mathrm{AC}$ activity was determined in aliquots of the same homogenate used for radioligand binding. Aliquots were incubated for $10 \mathrm{~min}$ at $30^{\circ} \mathrm{C}$ with final concentrations of $100 \mathrm{mM}$ Tris $\mathrm{HCl}$ ( $\mathrm{pH} 7.4$ ), $10 \mathrm{mM}$ theophylline, $1 \mathrm{mM}$ adenosine $5^{\prime}$-triphosphate, $10 \mu \mathrm{M}$ guanosine $5^{\prime}$-triphosphate, $2 \mathrm{mM} \mathrm{MgCl}_{2}, 1 \mathrm{mg} / \mathrm{ml}$ bovine serum albumin, and a creatine phosphokinase-ATP-regenerating system consisting of $10 \mathrm{mM}$ sodium phosphocreatine and $8 \mathrm{IU} / \mathrm{ml}$ phosphocreatine kinase. The enzymatic reaction was stopped by placing the samples in a $90-100^{\circ} \mathrm{C}$ water bath for $5 \mathrm{~min}$, followed by sedimentation at $3000 \mathrm{~g}$ for $15 \mathrm{~min}$, and the supernatant solution was assayed for cyclic AMP by radioimmunoassay. AC activity was evaluated under different conditions. To define basal and maximal activity, assays were conducted in the absence of any additions (basal AC) and in the presence of two direct AC stimulants that bypass the participation of neurotransmitter receptors: $100 \mu \mathrm{M}$ forskolin or $10 \mathrm{mM} \mathrm{Mn}^{2+}$. As the two stimulants act at different epitopes on the AC molecule, the preference for one over the other reflects shifts in molecular conformation, primarily influenced by the AC isoform (Zeiders et al, 1999). Third, we probed the AC response to $5 \mathrm{HT}$ receptor-mediated activation by determining the ratio of activity with $5 \mathrm{HT}$ to that without $5 \mathrm{HT}$, evaluated in samples stimulated with forskolin, an approach that enables detection of potential inhibitory or excitatory actions (Aldridge et al, 2003, 2004; Chow et al, 2000; Slotkin et al, 1999; Xu et al, 2002). The concentrations of all the agents used here have been found previously to be optimal for effects on AC (Aldridge et al, 2003; Meyer et al, 2003, 2004a, b).

\section{Data Analysis}

To avoid type I statistical errors that might result from repeated testing of the global data set, we first performed a global analysis of variance (ANOVA) (with log-transformed data because of heterogeneous variance) incorporating all the variables and measures: prenatal treatment, adolescent treatment, brain region, age, sex, and the multiple determinations (repeated measures) made on each membrane preparation for the different classes of measurements (receptor binding, AC activities). Lower-order ANOVAs were then run according to the interactions between treatment and the other variables. Where appropriate, this was followed by post hoc evaluations of each treatment group compared with the controls, using Fisher's Protected Least Significant Difference; however, where treatment effects did not interact with other variables only the main effect was recorded without testing of individual differences. Significance was assumed at the level of $p<0.05$ for main effects; however, for interactions at $p<0.1$, we also examined whether lower order main effects were detectable 
after subdivision of the interactive variables (Snedecor and Cochran, 1967).

The study design required two different ways of regarding treatment variables. To compare the effects of prenatal exposure alone, adolescent exposure, or the combined exposure to controls or to each other, the four treatment groups were considered as a one-dimensional factor in the statistical design. To determine whether the effects of prenatal exposure and adolescent exposure were interactive, the treatment factors were changed to a two-dimensional design. In this formulation, more-than-additive (synergistic) and less-than-additive effects appear as significant interactions between the two treatment dimensions, whereas simple, additive effects do not show significant interactions.

Data are presented as means and standard errors. To facilitate comparisons across multiple tissues, ages, and variables, the effects of each treatment are given as the percentage change from the corresponding control group, but statistical comparisons were made on the original data. For reference, control values are detailed in Table 1 .

\section{Materials}

Animals were purchased from Charles River Laboratories (Raleigh, NC) and osmotic minipumps from Durect Corp. (Cupertino, CA). Bacteriostatic water was obtained from
Abbott Laboratories (N Chicago, IL) and methylsergide from Sandoz Pharmaceuticals (E Hanover, NJ). PerkinElmer Life Sciences (Boston, MA) was the source for radioligands and cyclic AMP radioimmunoassay kits were purchased from GE Healthcare (Piscataway, NJ). Sigma Chemical Co. (St Louis, MO) was the source for all other reagents.

\section{RESULTS}

Across the age points from PN45 through PN75, prenatal nicotine treatment did not elicit significant reductions in body weight, but as reported earlier (Trauth et al, 1999, $2000 \mathrm{~b}$ ), adolescent nicotine reduced weights $<10 \%$ during treatment, with a rapid return to normal after nicotine was discontinued (not shown). The combination of prenatal + adolescent nicotine exposure elicited the same pattern of slight weight deficits and recovery as seen with adolescent treatment alone. None of the treatments evoked significant deficits in brain region weights, in accord with previous results (Abreu-Villaça et al, 2004a, b; Trauth et al, 1999, 2000b). In control animals, there were only sporadic sex differences in any of the neurochemical measures; in fact, no more than would be expected at random from the overall number of comparisons (Table 1). Nevertheless, as described below, nicotine treatment elicited sex-selective effects on many of the parameters.

Table I Control Values

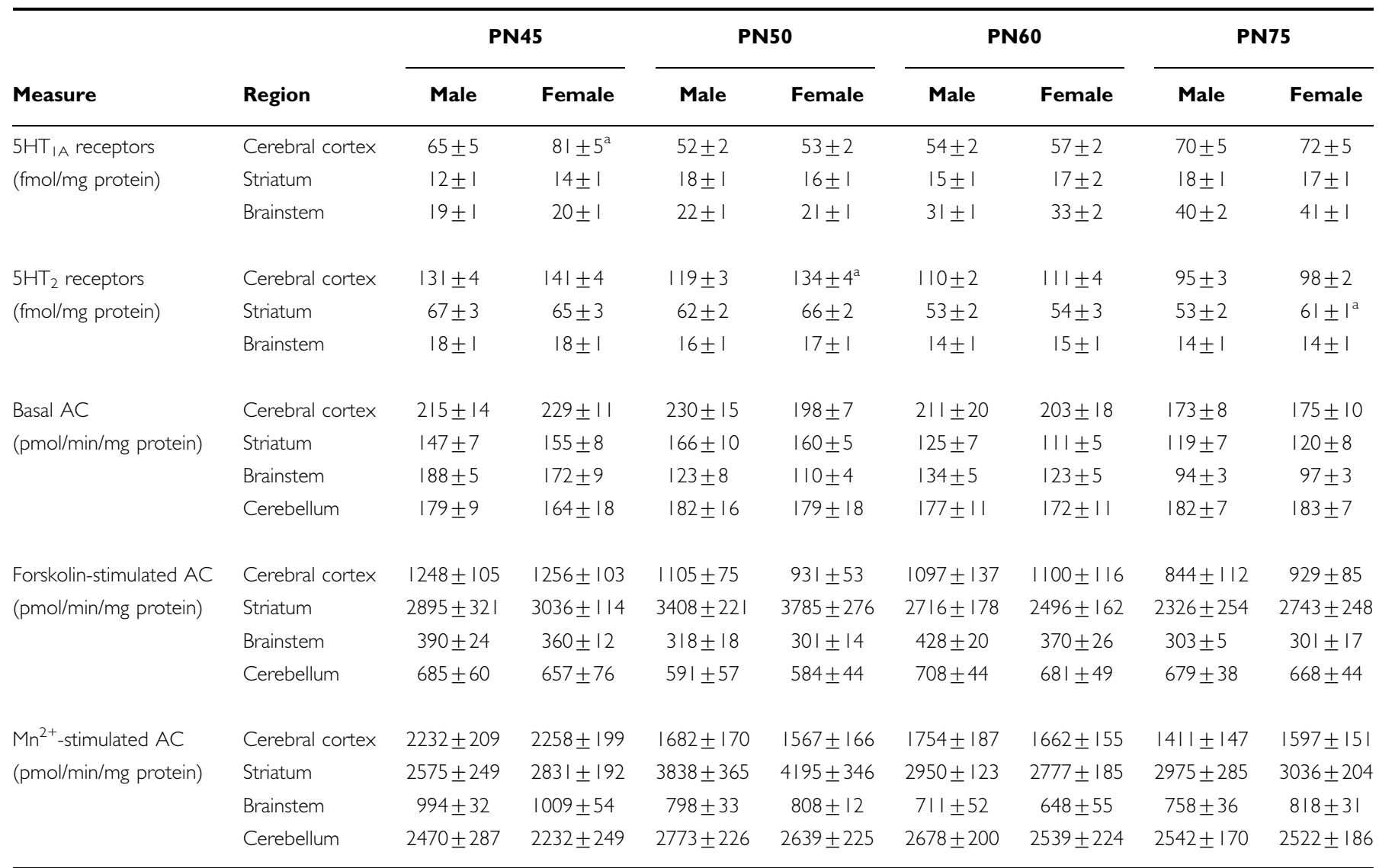

${ }^{a}$ Values for which females differ significantly from males. 


\section{Receptor Binding}

For 5HT receptor binding, global (ANOVA) across all contributing variables indicated a main effect of treatment $(p<0.03)$ and interactions of treatment $\times \operatorname{sex}(p<0.02)$, treatment $\times$ sex $\times$ region $(p<0.03)$, treatment $\times$ age $\times$ region $(p<0.07)$, treatment $\times$ sex $\times$ receptor subtype $(p<0.02)$, treatment $\times$ age $\times$ subtype $(p<0.0001)$, treatment $\times$ region $\times$ subtype $\quad(p<0.02), \quad$ treatment $\times$ sex $\times$ age $\times$ subtype $(p<0.0001)$, treatment $\times$ age $\times$ region $\times$ subtype $(p<0.004)$, and treatment $\times \operatorname{sex} \times$ region $\times$ subtype $(p<0.02)$. Since the receptor subtype interacted with all the other variables, we then performed separate analyses for $5 \mathrm{HT}_{1 \mathrm{~A}}$ and $5 \mathrm{HT}_{2}$ receptors. Both subtypes showed interactions of treatment with sex, age, and region: for $5 \mathrm{HT}_{1 \mathrm{~A}}$ receptors, $p<0.006$ for treatment $\times$ sex, $p<0.05$ for treatment $\times$ age, $p<0.02$ for treatment $\times$ sex $\times$ region, and $p<0.06$ for treatment $\times$ age $\times$ region; for $5 \mathrm{HT}_{2}$ receptors, $p<0.004$ for the main effect of treatment, $p<0.0001$ for treatment $\times$ age, $p<0.04$ for treatment $\times \operatorname{sex} \times$ age, $p<0.003$ for treatment $\times \operatorname{sex} \times$ region, $p<0.0007$ for treatment $\times$ age $\times$ region, and $p<0.07$ for treatment $\times \operatorname{sex} \times$ age $\times$ region. Since the treatment effects differed among regions (interactions of other variables $\times$ region), the results for each region were examined separately.

In the cerebral cortex, $5 \mathrm{HT}_{1 \mathrm{~A}}$ receptors showed significant treatment effects that depended upon age (treatment $\times$ age, $p<0.002$ ) and sex (treatment $\times$ sex, $p<0.05$; treatment $\times$ sex $\times$ age, $p<0.08$ ), necessitating separate consideration of values in males and females. In males, prenatal nicotine exposure elicited a significant overall elevation in $5 \mathrm{HT}_{1 \mathrm{~A}}$ receptor binding (Figure 1a). When nicotine was given instead during adolescence, $5 \mathrm{HT}_{1 \mathrm{~A}}$ receptor binding was elevated during the treatment and returned to normal in the post-treatment period. Animals exposed to nicotine prenatally and then given nicotine in adolescence displayed a significant overall elevation in receptor binding akin to that evoked by the prenatal exposure alone. In fact, animals receiving nicotine prenatally showed a blunted $5 \mathrm{HT}_{1 \mathrm{~A}}$ upregulation in response to adolescent nicotine, as evidenced by a significant interaction of prenatal $\times$ adolescent nicotine $(p<0.009)$, regarding the treatments as two separate dimensions; the animals receiving the combined treatment did not show the augmented $5 \mathrm{HT}_{1 \mathrm{~A}}$ receptor binding found in the animals given adolescent treatment alone. In females, there were no overall effects of any of the nicotine treatments on cerebrocortical $5 \mathrm{HT}_{1 \mathrm{~A}}$ receptor binding (Figure $1 b$ ).

Figure I Effects of prenatal and adolescent nicotine treatment on $5 \mathrm{HT}$ receptor binding in the cerebral cortex: (a) $5 \mathrm{HT}_{\mathrm{IA}}$ receptors in males; (b) $5 \mathrm{HT}_{1 \mathrm{~A}}$ receptors in females; (c) $5 \mathrm{HT}_{2}$ receptors combined for males and females because of the absence of a treatment $x$ sex interaction (see text). Values are presented as the percent change from control (Table I). ANOVA across all treatments and ages appears at the top of each panel and comparisons of each group to the control appears at the bottom; differences between nicotine administration groups are shown within the panel. Where there was a treatment $\times$ age interaction, asterisks denote individual ages at which the nicotine-treated animals show significant differences from the corresponding control values but in the absence of the interaction, only main treatment effects are indicated. $R x=$ treatment NS = not significant.
For cerebrocortical $5 \mathrm{HT}_{2}$ receptors, there was only a main treatment effect and an interaction of treatment $\times$ age, so values for males and females were combined for presentation (Figure 1c). Just as for $5 \mathrm{HT}_{1 \mathrm{~A}}$ receptors, prenatal nicotine exposure evoked a small but statistically significant

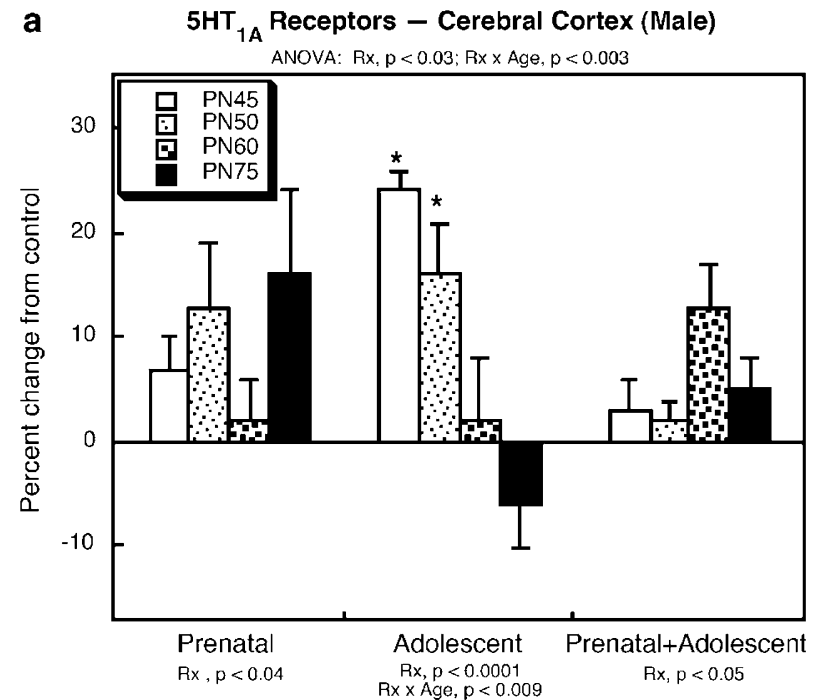

b $\quad 5 \mathrm{HT}_{1 \mathrm{~A}}$ Receptors - Cerebral Cortex (Female)

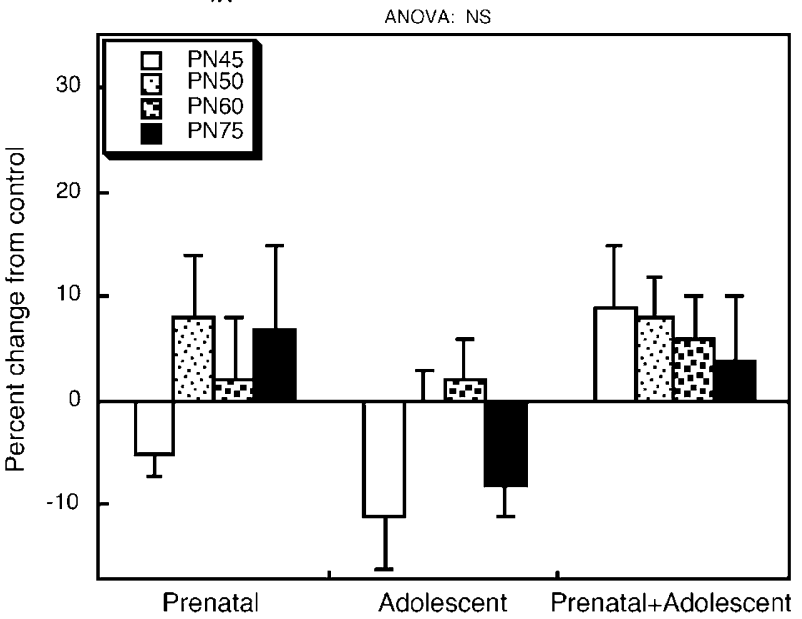

C $\quad 5 \mathrm{HT}_{2}$ Receptors - Cerebral Cortex

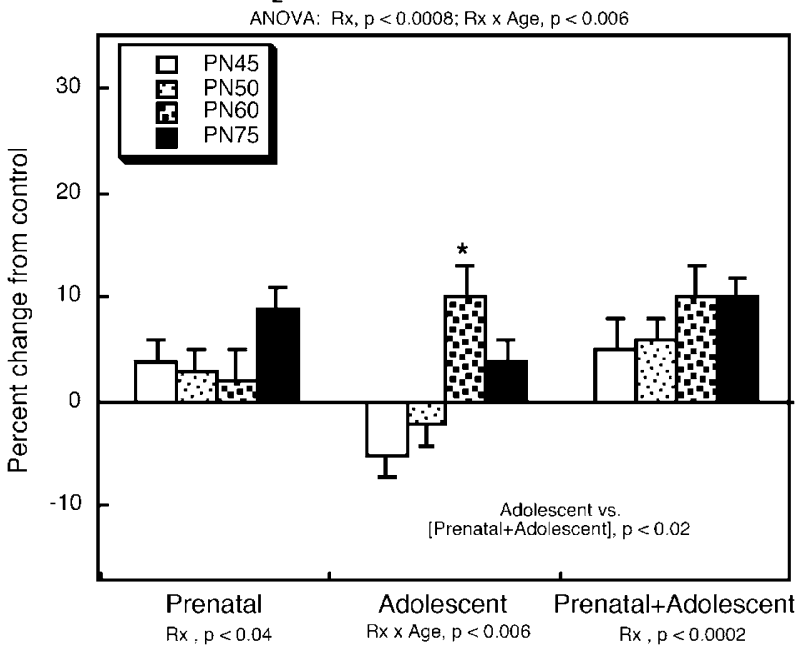


overall elevation of $5 \mathrm{HT}_{2}$ receptor binding. The response to adolescent nicotine administration was far more modest than that seen for the other receptor subtype, with a significant elevation obtained only upon withdrawal of nicotine (PN60). Again, animals exposed to nicotine prenatally and then given nicotine in adolescence showed essentially the same receptor effects as those exposed just prenatally.

In the striatum, both $5 \mathrm{HT}_{1 \mathrm{~A}}$ and $5 \mathrm{HT}_{2}$ receptors showed sex-dependent effects (treatment $\times$ sex interaction, $p<0.007$ and $p<0.004$ respectively), so values for males and females were separated for both subtypes. For $5 \mathrm{HT}_{1 \mathrm{~A}}$ receptors, males did not show any significant treatment-related changes (Figure 2a). Females exposed to nicotine prenatally showed significant overall reductions in $5 \mathrm{HT}_{1 \mathrm{~A}}$ receptor
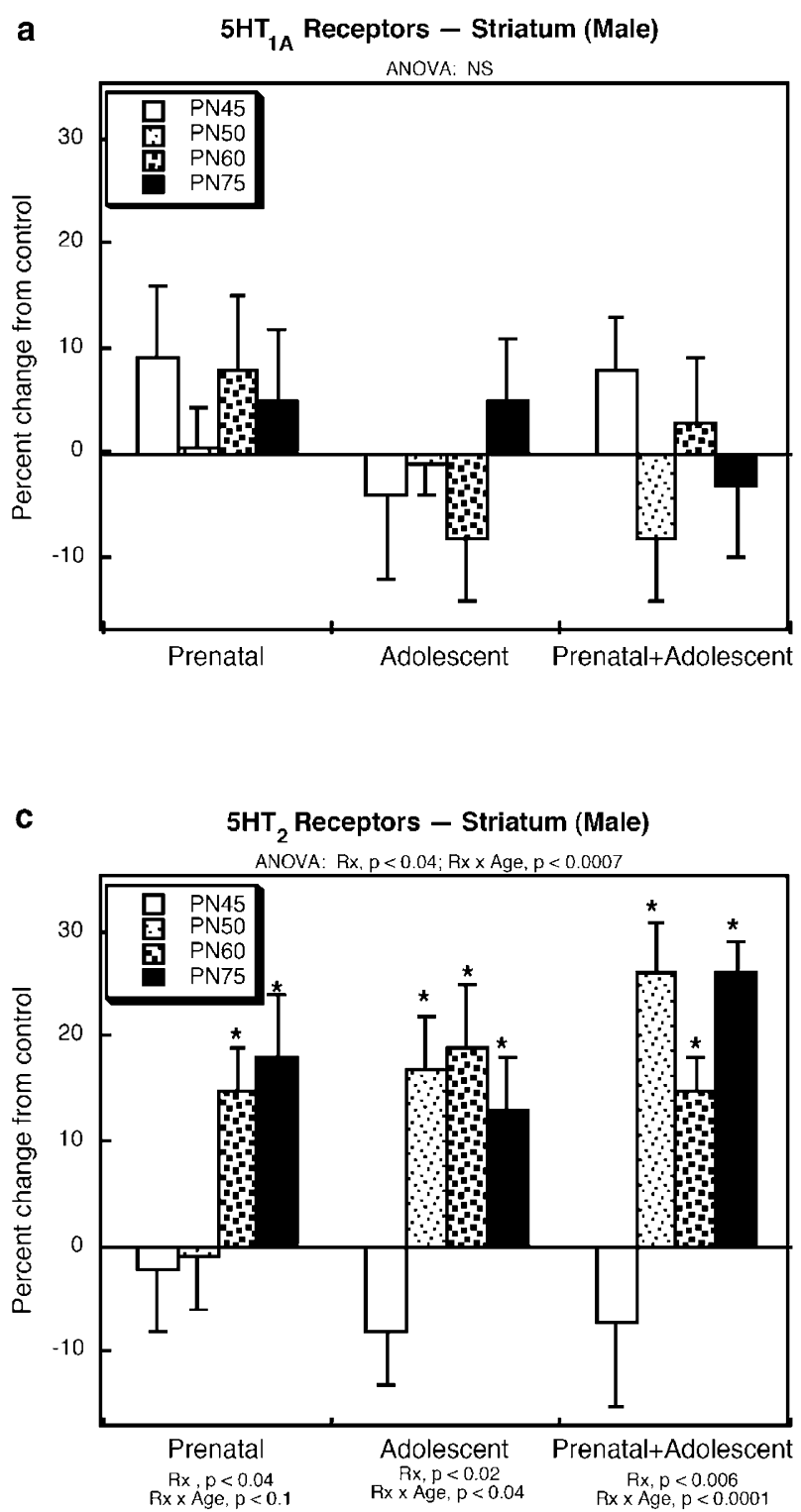

binding but the effects of adolescent nicotine exposure were less notable and nonsignificant (Figure $2 \mathrm{~b}$ ). Females given fetal nicotine exposure showed a completely different response to adolescent nicotine administration, characterized by robust increases in $5 \mathrm{HT}_{1 \mathrm{~A}}$ receptors, an effect that was not produced by either prenatal or adolescent treatment alone (prenatal $\times$ adolescent nicotine, $p<0.007$ ). Regarding prenatal and adolescent nicotine treatments as separate dimensions in ANOVA, there was a significant interaction of the two treatments $(p<0.007)$, confirming the fact that the group with combined exposure was statistically distinguishable from either of the two groups or from the summation of individual effects.

For striatal $5 \mathrm{HT}_{2}$ receptors, the nicotine treatments elicited significant changes for both sexes, but again with
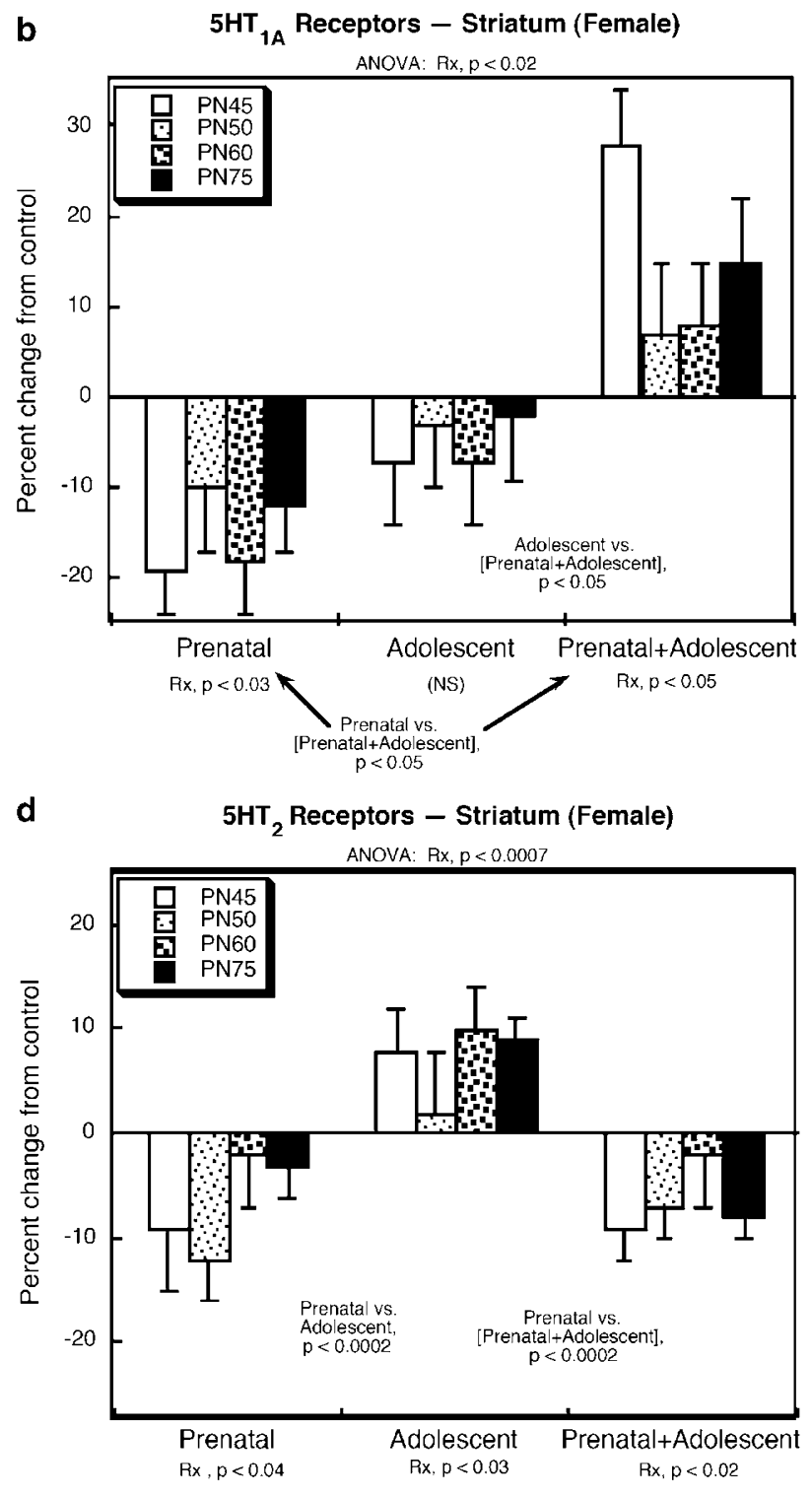

Figure 2 Effects of prenatal and adolescent nicotine treatment on $5 \mathrm{HT}$ receptor binding in the striatum: (a) $5 \mathrm{HT}_{\mid \mathrm{A}}$ receptors in males; (b) $5 \mathrm{HT}$ ।A receptors in females; (c) $5 \mathrm{HT}_{2}$ receptors in males; (d) $5 \mathrm{HT}_{2}$ receptors in females. Values are presented as the percent change from control (Table I). ANOVA across all treatments and ages appears at the top of each panel and comparisons of each group to the control appears at the bottom; differences between nicotine administration groups are shown either within or below the panel as indicated. Where there was a treatment $x$ age interaction, asterisks denote individual ages at which the nicotine-treated animals show significant differences from the corresponding control values but in the absence of the interaction, only main treatment effects are indicated. $R \times=$ treatment; $N S=$ not significant. 
a different pattern in males $v s$ females. In males, prenatal nicotine exposure evoked an increase in receptor binding with an onset corresponding to the eighth postnatal week (Figure 2c). Adolescent nicotine administration had a similar effect, with increases appearing only after the termination of nicotine treatment but persisting into adulthood. In this case, males exposed to nicotine prenatally and then given nicotine in adolescence showed an increase in $5 \mathrm{HT}_{2}$ receptors that corresponded to the summation of the two individual effects, that is, no interaction of prenatal $\times$ adolescent nicotine, regarding the two treatments as separate dimensions in ANOVA. Females exposed to prenatal nicotine displayed an overall decrease in striatal $5 \mathrm{HT}_{2}$ receptors, whereas adolescent nicotine treatment produced an increase, just as had been seen for males, albeit to a smaller degree (Figure $2 \mathrm{~d}$ ). When females were exposed to nicotine prenatally, the striatal $5 \mathrm{HT}_{2}$ receptor response to adolescent nicotine was desensitized: the effects of the combined treatment were indistinguishable from that of prenatal nicotine alone, so that the adolescent nicotine treatment had essentially no effect in this group.

In the brainstem, $5 \mathrm{HT}_{1 \mathrm{~A}}$ receptors did not display significant effects of treatment (Figure 3a). For the $5 \mathrm{HT}_{2}$ subtype, there were significant effects that did not depend on sex (no interaction of treatment $\times$ sex or of treatment $\times$ sex $\times$ age), so values for males and females were combined for presentation (Figure $3 \mathrm{~b}$ ). As was found in the cerebral cortex, $5 \mathrm{HT}_{2}$ receptors in the brainstem showed overall upregulation in the animals exposed to prenatal nicotine. However, adolescent treatment had little or no effect and the combination of prenatal nicotine followed by adolescent treatment displayed essentially the same pattern as that achieved with fetal exposure alone.

We did not conduct measurements of 5HT receptors in the cerebellum because of the sparsity of $5 \mathrm{HT}$ innervation in that region. Instead, we assessed $\beta A R$ binding, a corresponding measure for norepinephrine, the monoamine most prevalent in the cerebellum. Across all treatments, we found a main effect of nicotine $(p<0.02)$ without interactions for age and sex, so for concision, the values are given collapsed across the four age points and combined for males and females: control, $32.3 \pm 0.2 \mathrm{fmol} / \mathrm{mg}$ protein; prenatal nicotine, $31.1 \pm 0.2(p<0.05 v s$ control); adolescent nicotine, $31.9 \pm 0.3$; prenatal + adolescent nicotine, $30.3 \pm 0.2$ $(p<0.004$ vs control, $p<0.02$ vs adolescent nicotine). Thus, prenatal treatment decreased cerebellar $\beta$ AR expression by a small but statistically significant extent, adolescent nicotine had little or no effect, and the combined treatment displayed effects akin to those of prenatal treatment alone.

Effects on $5 \mathrm{HT}_{1 \mathrm{~A}}$ receptor expression early in life can influence the subsequent concentration of receptors in adulthood (Kusserow et al, 2004). Accordingly, we evaluated whether prenatal nicotine treatment affects $5 \mathrm{HT}_{1 \mathrm{~A}}$ receptors during the period in which the fetal brain is exposed to nicotine (GD18) or in the immediate postnatal period (PN4). We found an overall, significant increase in $5 \mathrm{HT}_{1 \mathrm{~A}}$ receptors in the forebrain $(p<0.04$ for the main treatment effect), without interactions with age or sex: GD18, control $6.5 \pm 0.5 \mathrm{fmol} / \mathrm{mg}$ protein, nicotine $8.4 \pm 0.7$; PN4, control $34 \pm 1$, nicotine $37 \pm 1$.
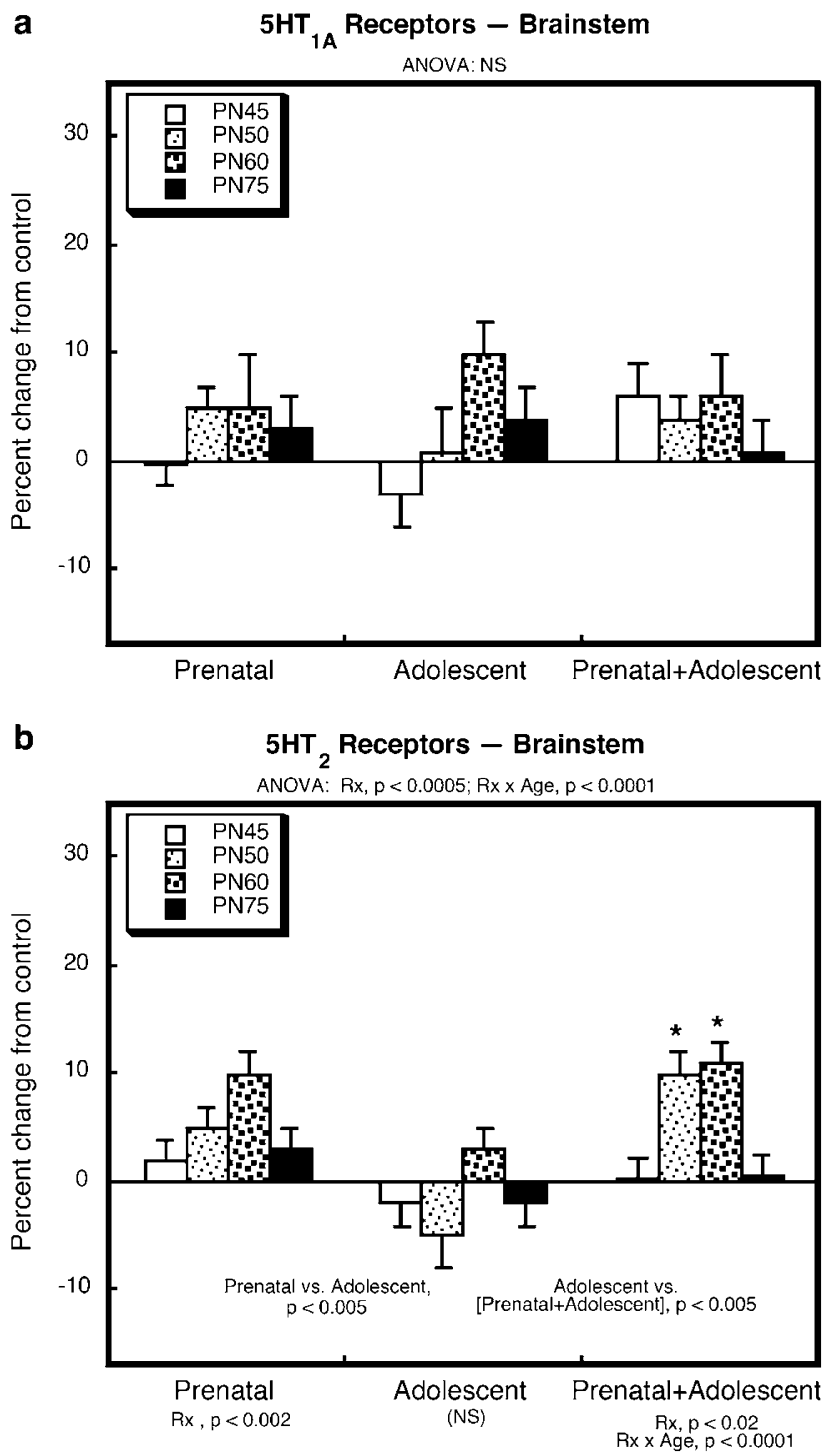

Figure 3 Effects of prenatal and adolescent nicotine treatment on $5 \mathrm{HT}$ receptor binding in the brainstem, shown combined for males and females because of the absence of a treatment $\times$ sex interaction (see text): (a) $5 \mathrm{HT}_{\text {IA }}$ receptors; (b) $5 \mathrm{HT}_{2}$ receptors. Values are presented as the percent change from control (Table I). ANOVA across all treatments and ages appears at the top of each panel and comparisons of each group to the control appears at the bottom; differences between nicotine administration groups are shown within the panel. Where there was a treatment $x$ age interaction, asterisks denote individual ages at which the nicotine-treated animals show significant differences from the corresponding control values but in the absence of the interaction, only main treatment effects are indicated. $\mathrm{Rx}=$ treatment; $\mathrm{NS}=$ not significant.

\section{Cell Signaling}

Across all treatments, brain regions, AC measures (basal, forskolin-stimulated, and $\mathrm{Mn}^{2+}$-stimulated activity) and both sexes, ANOVA identified a main effect of treatment $(p<0.006)$ that depended upon age, region, and measure, but not sex $(p<0.03$ for treatment $\times$ age, $p<0.02$ for treatment $\times$ region, $p<0.03$ for treatment $\times$ age $\times$ region, $p<0.0001$ for treatment $\times$ measure). Accordingly, results were examined separately for the various regions, but with values for males and females combined. In the cerebral cortex, prenatal nicotine exposure elicited a significant 
a
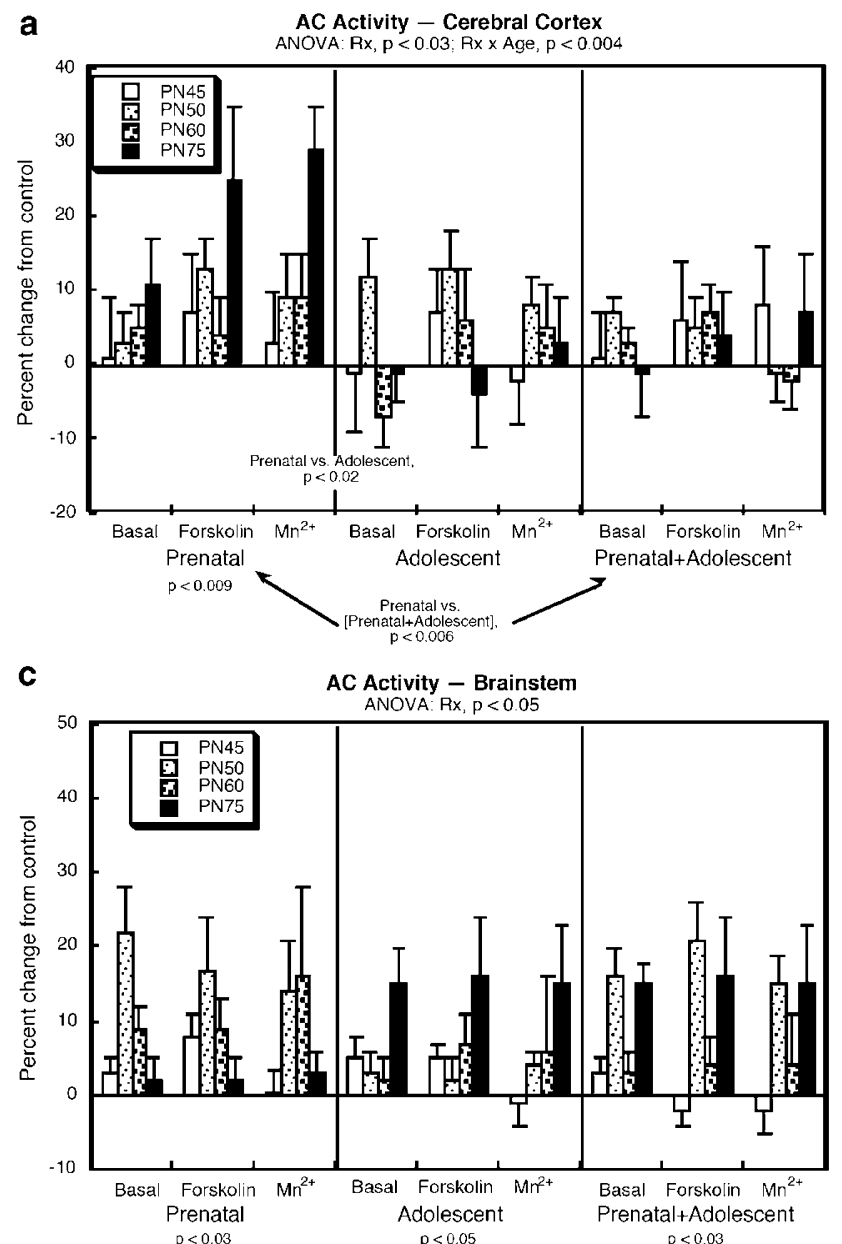

b AC Activity - Striatum

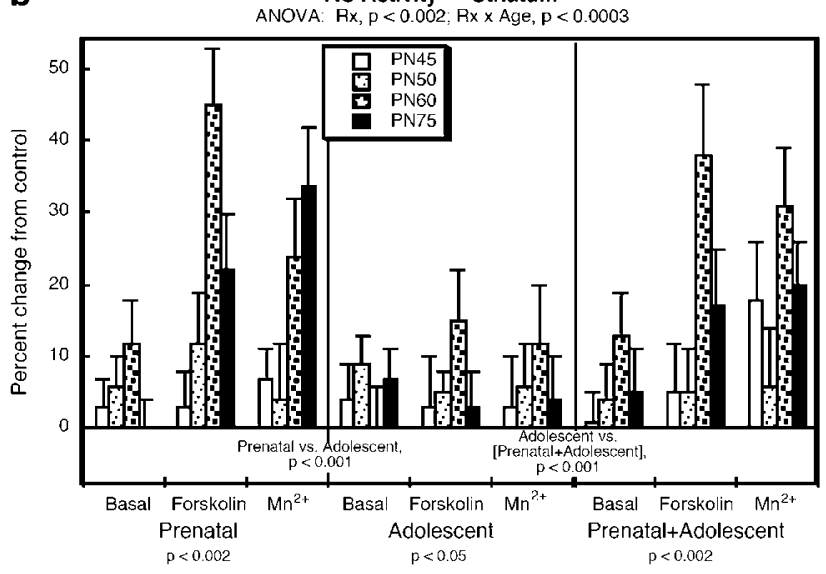

d AC Activity - Cerebellum

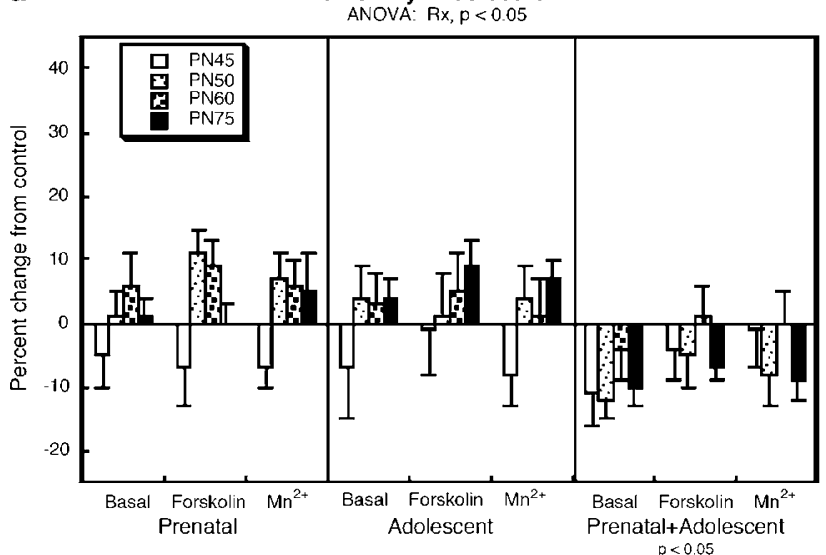

Figure 4 Effects of prenatal and adolescent nicotine treatment on basal $A C$ activity and the response to the direct $A C$ stimulants, forskolin and $M n^{2+}$, shown combined for males and females because of the absence of a treatment $\times$ sex interaction (see text): (a) cerebral cortex; (b) striatum; (c) brainstem; (d) cerebellum. Values are presented as the percent change from control (Table I). ANOVA across all treatments and ages, and all three AC measures, appears at the top of each panel and comparisons of each group to the control appears at the bottom; differences between nicotine administration groups are shown within or below the panel, as indicated. Separate statistical analyses for individual measures or ages was not undertaken because of the absence of treatment interactions with these two variables (see text), so that only main treatment effects are indicated. $R \times=$ treatment.

overall increase in $\mathrm{AC}$ activities, whereas the effects of adolescent nicotine were smaller and did not achieve statistical significance (Figure 4a). However, when animals given prenatal nicotine were treated again with nicotine in adolescence, the net effect on AC activity was actually lower than the values achieved with the prenatal treatment alone; that is, in these animals, adolescent nicotine treatment actually reduced $\mathrm{AC}$ activity relative to the values achieved with just the prenatal treatment. Although none of the individual treatment paradigms showed a significant treatment $\times$ age interaction, the overall data set did, reflecting a trend toward increased effect with advancing age.

For striatal AC, prenatal nicotine exposure produced a robust overall increase, again to a much greater extent than that evoked by adolescent treatment, both of which achieved statistical significance (Figure $4 \mathrm{~b}$ ). In this region, the combination of prenatal nicotine exposure followed by nicotine treatment in adolescence produced effects that were indistinguishable from those of prenatal nicotine alone. Again, there was an overall increase in effect with age (significant treatment $\times$ age interaction). In the brainstem, prenatal nicotine, adolescent nicotine, or the combination of both treatments all produced significant overall elevations of AC activity (Figure 4c). In contrast, the only effect seen in the cerebellum was a small, but statistically significant decrease in the animals receiving the combined prenatal and adolescent treatments (Figure 4d).

Besides the basic measurements of AC activity, we also evaluated whether any of the nicotine treatment paradigms altered the response of forskolin relative to $\mathrm{Mn}^{2+}$; there were no significant differences in the response ratio (not shown). Since earlier work demonstrated a shift in the AC response to 5HT receptor stimulation evoked by withdrawal from nicotine in adolescence ( $\mathrm{Xu}$ et al, 2002), we next assessed this effect in animals exposed to nicotine prenatally, given nicotine in adolescence, or receiving the combination (Figure 5). In control animals, $5 \mathrm{HT}$ produced a net decrease in AC in the cerebral cortex and stimulation in the striatum, with a fairly neutral balance in the brainstem. As noted earlier, the magnitude of the 5HT-mediated AC responses reflects the small proportion of total AC activity specifically linked to 5HT receptors, as well as the fact that the different subtypes are linked both to stimulation and 


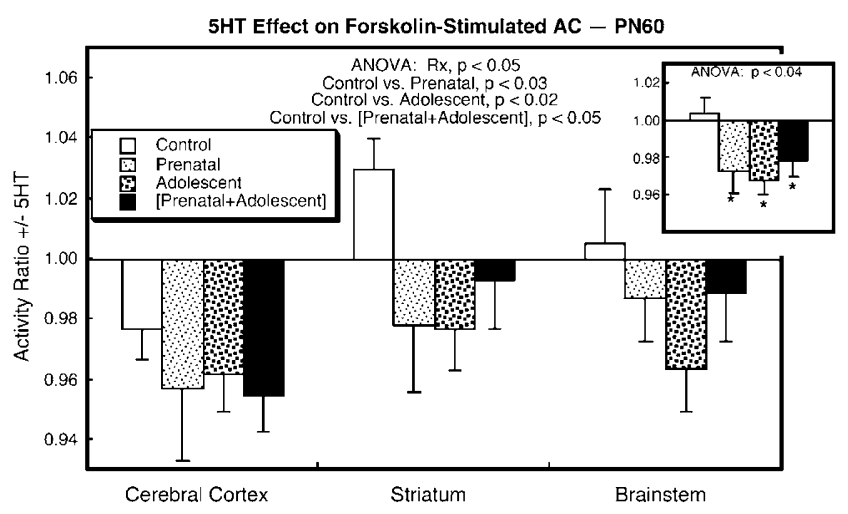

Figure 5 Effects of prenatal and adolescent nicotine treatment on the AC response to $5 \mathrm{HT}$ on $\mathrm{PN60}$, assessed as the ratio of forskolin-stimulated activity with addition of $5 \mathrm{HT}$ to forskolin-stimulated activity without $5 \mathrm{HT}$. ANOVA across all regions appears at the top of the panel and the inset shows the net effect collapsed across all three regions because of the absence of a treatment $\times$ region interaction; in the inset, asterisks denote individual treatments that differ from the corresponding control.

inhibition (Aldridge et al, 2005; Xu et al, 2002). In each region, prenatal nicotine, adolescent nicotine, or the combined treatment altered the AC response to $5 \mathrm{HT}$ by increasing the inhibitory component. Collapsed across all three regions (because of the lack of treatment $\times$ region interactions), the net effect of 5HT was relatively neutral in controls but inhibitory in each of the three different nicotine groups, all of which displayed approximately the same degree of effect (Figure 5 inset). Again, then, the prenatal treatment interfered with the ability of adolescent nicotine to cause a further effect.

\section{DISCUSSION}

\section{Prenatal Nicotine Exposure}

In earlier work, we found that prenatal nicotine exposure elicits persistent loss of 5HT projections and reactive sprouting at the cell bodies (Xu et al, 2001). Accordingly, the increase seen here for 5HT receptor binding in brain regions containing 5HT terminals likely represents compensatory upregulation consequent to the reduction in 5HT input. Indeed the magnitude of the changes in receptor expression approximates the degree of synaptic loss noted earlier (Xu et al, 2001). In keeping with this interpretation, the brainstem, which contains the majority of 5HT cell bodies, showed less effect, with no significant increases in $5 \mathrm{HT}_{1 \mathrm{~A}}$ receptors and only a small increase in the $5 \mathrm{HT}_{2}$ subtype. Our findings further indicate that the changes in $5 \mathrm{HT}$ receptors originate very early in development, during and immediately after the period of prenatal nicotine exposure. Earlier work with animals genetically modified to over- or underproduce $5 \mathrm{HT}_{1 \mathrm{~A}}$ receptors showed that the perinatal period is a critical phase for programming future receptor expression and function (Kusserow et al, 2004), so that the ability of prenatal nicotine exposure to cause early receptor upregulation itself is likely to contribute additionally to the lasting effects on 5HT receptors in adolescence and adulthood. There were notable sex differences in the receptor effects, which will be discussed later. Superimposed on the changes in 5HT receptor expression, prenatal nicotine exposure also altered 5HTmediated AC signaling, enhancing the inhibitory component of the response. Again, this result is in keeping with conclusions reached from genetic models, where perinatal $5 \mathrm{HT}_{1 \mathrm{~A}}$ receptor overexpression was found to reduce 5HTrelated anxiety in adulthood (Kusserow et al, 2004).

It is clear from our results that prenatal nicotine alters 5HT cellular responses not just through effects on homologous mechanisms but rather involves global, heterologous changes in AC itself. In fact, the largest changes in cell signaling involved the response to direct AC stimulants, forskolin and $\mathrm{Mn}^{2+}$, that bypass the requirement for receptor activation; there was no preferential shift in the response to forskolin $v s \mathrm{Mn}^{2+}$, so that it is most likely that the increase in $\mathrm{AC}$ catalytic activity represents overexpression of AC itself (Zeiders et al, 1999). Unlike the receptor effects, the increases in overall AC activity were similar in the cerebral cortex and brainstem, and only slightly larger in the striatum, and did not show the sex differences noted for receptor upregulation. Accordingly, these differences imply that the heterologous effects have a different originating mechanism from those targeted specifically toward 5HT systems. Indeed, the general effects of prenatal nicotine exposure on cellular development, differentiation, and synaptogenesis reflect actions mediated through nAChRs in the fetal brain, rather than affecting only $5 \mathrm{HT}$ projections (Slotkin, 1998, 2004). The smaller effects seen in the cerebellum are thus a likely consequence of the sparsity of cholinergic projections and receptors in that region. In any case, the heterologous effects on AC are of key importance in the neurobehavioral teratology of nicotine, given the convergence of multiple neurotransmitter and hormonal inputs on this signaling pathway. Future work is thus needed to examine AC responses and the corresponding behavioral changes to a variety of neurotransmitters in the prenatal nicotine model.

\section{Nicotine Administration in Adolescence}

By itself, nicotine treatment in adolescence also elicited significant changes in 5HT receptor expression, 5HTmediated cellular responses, and heterologous aspects of AC signaling, comparable to those reported earlier ( $\mathrm{Xu}$ et al, 2002). In general, these were similar in direction to those noted for prenatal nicotine exposure, but frequently smaller in magnitude, in keeping with the lower vulnerability of the adolescent brain to nicotine-induced neurotoxicity and the closure of developmental events delineating synaptic organization and the programming of synaptic activity (Slotkin, 2002). As these have been discussed in detail in earlier reports (Abreu-Villaça et al, 2003b; Slotkin, 2002; Xu et al, 2002), only a few salient features will be noted here. With adolescent nicotine treatment, just as with prenatal nicotine exposure, we found upregulation of cerebrocortical $5 \mathrm{HT}_{1 \mathrm{~A}}$ and $5 \mathrm{HT}_{2}$ receptors, except that there was a clear relationship to the periods of administration and discontinuation of nicotine in the adolescent model: the $5 \mathrm{HT}_{1 \mathrm{~A}}$ subtype was increased by nicotine treatment and returned to normal in the post-treatment period, whereas the $5 \mathrm{HT}_{2}$ subtype was increased only after nicotine was discontinued. In the striatum, only the $5 \mathrm{HT}_{2}$ subtype showed significant 
adolescent nicotine-induced alterations, and again, this was primarily related to the period after discontinuing nicotine treatment. It is therefore highly likely that the receptor alterations with adolescent nicotine, unlike those after prenatal nicotine exposure, represent short-term responses to nicotine treatment and withdrawal, rather than effects on long-term programming of receptor expression. In accord with this interpretation, the primary outcome for 5HTmediated cell signaling is also restricted to the posttreatment period and is transient ( $\mathrm{Xu}$ et al, 2002). This was reproduced in the current study: as with prenatal nicotine, the net effect of adolescent nicotine on the AC response to 5HT was promotion of inhibitory responses during withdrawal on PN60. In additional studies, we found that the effect of discontinuing nicotine treatment was much more profound for the response to 5HT than for catecholaminergic receptors linked to $\mathrm{AC}$, implying that there is a preferential effect of adolescent nicotine withdrawal on 5HT function (Abreu-Villaça et al, 2003b; Xu et al, 2002). Again, behavioral consequences of this alteration in 5HT signaling would be interesting to explore, especially given the specific relationship of $5 \mathrm{HT}$ to mood disorders (Maes and Meltzer, 1995) and the prevalence of depression in adolescent smokers (Goodman and Capitman, 2000; Patten et al, 2000; Wu and Anthony, 1999).

\section{Effects of Prenatal Nicotine Exposure on the Response to Nicotine in Adolescence}

In earlier work, we found that prenatal nicotine exposure produces lasting deficiencies in cholinergic neurotransmission, including decreased presynaptic activity and lasting nAChR desensitization (Abreu-Villaça et al, 2004b; Seidler et al, 1992; Slotkin, 1998, 2002, 2004). As a result, nicotine administered in adolescence then produces a reduced net response and a smaller degree of $\mathrm{nAChR}$ upregulation (Abreu-Villaça et al, 2004b; Seidler et al, 1992). The current results indicate a similar loss of responsiveness for the effects of nicotine on 5HT systems. Thus, for many of the indices, animals exposed to prenatal nicotine did not show any further change upon nicotine administration in adolescence. The best examples are provided by the measurements of cerebrocortical $5 \mathrm{HT}_{1 \mathrm{~A}}$ and $5 \mathrm{HT}_{2}$ receptor binding, striatal $5 \mathrm{HT}_{2}$ receptors in females, $\mathrm{AC}$ activity in the striatum and brainstem, and the shift of the 5HTmediated AC response toward greater inhibition; in each of these cases, animals given prenatal and adolescent nicotine displayed the same response as that achieved with prenatal nicotine alone, indicating essentially no response to adolescent nicotine. In contrast, the effects on striatal $5 \mathrm{HT}_{2}$ receptor binding in males were additive, indicating that prenatal nicotine did not change the response to adolescent nicotine for this parameter. However, the most striking interactions were seen for cerebrocortical AC activity and for striatal $5 \mathrm{HT}_{1 \mathrm{~A}}$ receptors in females. Prenatal nicotine evoked a persistent elevation of $\mathrm{AC}$ in the cerebral cortex, and by itself, adolescent nicotine was only slightly (nonsignificantly) stimulatory. However, when animals with prenatal nicotine exposure were given nicotine in adolescence, the adolescent treatment actually reduced the effect of prenatal nicotine, lowering the net change to nearly zero; this implies that although adolescent nicotine administration has a slight stimulatory effect by itself, when it is administered to animals exposed earlier to prenatal nicotine, it actually inhibits the AC response, neutralizing the long-term effect of the fetal treatment. For striatal $5 \mathrm{HT}_{1 \mathrm{~A}}$ receptors, prenatal or adolescent nicotine alone tended to reduce expression in females, but the combined treatment produced significant elevations, so that once again the response to adolescent nicotine was drastically altered by prenatal nicotine. For this latter unique effect, there may be a significant contribution from nicotineinduced neuronal damage. Nicotine selectively upregulates striatal $\alpha 7 \mathrm{nAChRs}$ in adolescent rats (Slotkin et al, 2004), the subtype associated with plasticity and responses to damage (Broide and Leslie, 1999; Shimohama et al, 1998). Both smoking and nicotine release large concentrations of dopamine in the striatum (Brody et al, 2004), leading to oxidative damage (Qiao et al, 2005), as is characteristic of this neurotransmitter (Olanow and Arendash, 1994). Accordingly, there may be cumulative damage after prenatal and adolescent nicotine that contributes to atypical effects on striatal $5 \mathrm{HT}$ systems. If this is so, then antioxidant strategies may be able to prevent or offset the effects, a possible avenue for future work.

For virtually all the parameters, then, prenatal nicotine exposure elicits profound alterations in the response of $5 \mathrm{HT}$ systems and AC signaling to adolescent nicotine treatment, most of which involve lasting desensitization but some of which involve unique responses that are not typically seen with prenatal or adolescent nicotine alone. In fact, these patterns may not be specific to nicotine effects on 5HT systems, since we found similar desensitization for cholinergic systems (Abreu-Villaça et al, 2004b; Seidler et al, 1992). Indeed, given the prominent role of cholinergic input in regulating $5 \mathrm{HT}$ synaptic activity (Cucchiaro and Commons, 2003; Rao et al, 2003; Seth et al, 2002), the parallel findings may reflect a primary effect of prenatal nicotine exposure on cholinergic synaptic activity and responsiveness, secondarily influencing 5HT systems (Abreu-Villaça et al, 2004b; Seidler et al, 1992; Slotkin, 1998, 2002, 2004). Superimposed on this overall effect, the cumulative neurotoxicity imposed by the combined prenatal and adolescent nicotine exposure may then account for the additional alterations in $5 \mathrm{HT}$ and $\mathrm{AC}$ responses that show directions of change opposite to those of either treatment alone (Abreu-Villaça et al, 2004a; Slotkin, 2002). Future work detailing the anatomical relationship of 5HT systems to nicotine-induced brain damage should elucidate these mechanisms. In any case, the relatively smaller effects of any of the treatments on the cerebellum, a region sparse in cholinergic projections and nAChRs, points to the importance of receptor-mediated events in producing the lasting effects on cell signaling.

Both prenatal and adolescent nicotine treatments, alone or in combination, displayed sex selectivity in the effects on 5HT receptor expression. These results are consistent with previous work with prenatal nicotine treatment, which showed male-female differences in neurochemical and behavioral outcomes and in the synthesis of sex steroids (Lichtensteiger and Schlumpf, 1985; Pauly et al, 2004; Sarasin et al, 2003; Segarra and Strand, 1989; Tizabi et al, 1997). These have distinct parallels in the effects of maternal smoking during pregnancy on behavior, which is similarly 
gender-selective (Fergusson et al, 1998; Wakschlag and Hans, 2002; Wakschlag et al, 1997). Adolescent nicotine administration in animal models also shows distinct sex differences, both in the present study and in previous work from our and other laboratories (Faraday et al, 2001; Klein et al, 2004; Slotkin, 2002; Slotkin et al, 2002; Xu et al, 2002, 2003). Furthermore, gender selectivity also been reported for the initiation of smoking in individuals who were exposed in utero (Oncken et al, 2004).

The key remaining question is the extent to which prenatal nicotine exposure alters nicotine dependence or withdrawal in adolescence, and whether 5HT systems and AC signaling contribute to these outcomes. Although our studies do not address these issues directly, for the majority of biomarkers, the in utero treatment elicited a pattern of alterations in the same direction as those elicited by withdrawal of nicotine in the adolescent treatment model, only with a greater magnitude of effect. These animals are therefore in the same state of 5HT and AC function as would be expected in the adolescent during withdrawal after nicotine administration. Interestingly, this interpretation is in keeping with a recent hypothesis of the origin of nicotine dependence, the 'sensitization-homeostasis theory' (DiFranza and Wellman, 2005), which postulates that the stimulatory and inhibitory adjustments to nicotine administration produce reversible as well as permanent changes in activity of specific neuronal circuits. The fact that alterations in 5HT synaptic signaling emerge upon discontinuation of adolescent nicotine administration, and that prenatal nicotine exposure alters the pattern of such reactivity, are all in keeping with this model, and similarly suggest that persistent changes will leave prenatally exposed individuals vulnerable to relapse upon cessation of adolescent smoking (DiFranza and Wellman, 2005). Indeed, studies in adolescent smokers show emergence of both cognitive impairment and depression upon smoking cessation, contributing to the failure to quit (Colby et al, 2000; Goodman and Capitman, 2000; Hurt et al, 2000; Martini et al, 2002; Patten et al, 2000; Salin-Pascual et al, 1995; Tsoh et al, 2000; Wu and Anthony, 1999). Just as predicted by our findings in animals, these problems are worsened in adolescent smokers who were exposed in utero via maternal smoking (Oncken et al, 2004), with the differences from other adolescent smokers emerging prominently during withdrawal (Jacobsen et al, 2005, 2006). Accordingly, animal models of prenatal and adolescent nicotine exposure are likely to provide a biological basis for the creation of subpopulations that are especially vulnerable to nicotine dependence and withdrawal in adolescence.

\section{ACKNOWLEDGEMENTS}

We thank Justin Aldridge and Leah DiMascio for technical assistance. Research was supported by a grant from the External Research Program of Philip Morris USA, Inc.

\section{REFERENCES}

Abreu-Villaça Y, Seidler FJ, Qiao D, Tate CA, Cousins MM, Thillai I et al (2003a). Short-term adolescent nicotine exposure has immediate and persistent effects on cholinergic systems: critical periods, patterns of exposure, dose thresholds. Neuropsychopharmacology 28: 1935-1949.

Abreu-Villaça Y, Seidler FJ, Slotkin TA (2003b). Impact of adolescent nicotine exposure on adenylyl cyclase-mediated cell signaling: enzyme induction, neurotransmitter-specific effects, regional selectivities, and the role of withdrawal. Brain Res 988: 164-172.

Abreu-Villaça Y, Seidler FJ, Slotkin TA (2004a). Does prenatal nicotine sensitize the brain to nicotine-induced neurotoxicity in adolescence? Neuropsychopharmacology 29: 1440-1450.

Abreu-Villaça Y, Seidler FJ, Tate CA, Cousins MM, Slotkin TA (2004b). Prenatal nicotine exposure alters the response to nicotine administration in adolescence: effects on cholinergic systems during exposure and withdrawal. Neuropsychopharmacology 29: 879-890.

Abreu-Villaça Y, Seidler FJ, Tate CA, Slotkin TA (2003c). Nicotine is a neurotoxin in the adolescent brain: critical periods, patterns of exposure, regional selectivity, and dose thresholds for macromolecular alterations. Brain Res 979: 114-128.

Adriani W, Macri S, Pacifici R, Laviola G (2002). Peculiar vulnerability to nicotine oral self-administration in mice during early adolescence. Neuropsychopharmacology 27: 212-224.

Adriani W, Spijker S, Deroche-Gamonet V, Laviola G, Le Moal M, Smit $\mathrm{AB}$ et al (2003). Evidence for enhanced neurobehavioral vulnerability to nicotine during periadolescence in rats. $J$ Neurosci 23: 4712-4716.

Aldridge JE, Meyer A, Seidler FJ, Slotkin TA (2005). Developmental exposure to terbutaline and chlorpyrifos: pharmacotherapy of preterm labor and an environmental neurotoxicant converge on serotonergic systems in neonatal rat brain regions. Toxicol Appl Pharmacol 203: 134-144.

Aldridge JE, Seidler FJ, Meyer A, Thillai I, Slotkin TA (2003). Serotonergic systems targeted by developmental exposure to chlorpyrifos: effects during different critical periods. Environ Health Perspect 111: 1736-1743.

Aldridge JE, Seidler FJ, Slotkin TA (2004). Developmental exposure to chlorpyrifos elicits sex-selective alterations of serotonergic synaptic function in adulthood: critical periods and regional selectivity for effects on the serotonin transporter, receptor subtypes, and cell signaling. Environ Health Perspect 112: 148-155.

Arango V, Underwood MD, Boldrini M, Tamir H, Kassir SA, Hsiung $S$ et al (2001). Serotonin-1A receptors, serotonin transporter binding and serotonin transporter mRNA expression in the brainstem of depressed suicide victims. Neuropsychopharmacology 25: 892-903.

Barnes NM, Sharp T (1999). A review of central 5-HT receptors and their function. Neuropharmacology 38: 1083-1152.

Brody AL, Olmstead RE, London ED, Farahi J, Meyer JH, Grossman $\mathrm{P}$ et al (2004). Smoking-induced ventral striatum dopamine release. Am J Psychiat 161: 1211-1218.

Broide RS, Leslie FM (1999). The $\alpha 7$ nicotinic acetylcholine receptor in neuronal plasticity. Mol Neurobiol 20: 1-16.

Chassin L, Presson CC, Rose JS, Sherman SJ (1996). The natural history of cigarette smoking from adolescence to adulthood: demographic predictors of continuity and change. Health Psychol 15: 478-484.

Chen J, Millar WJ (1998). Age of smoking inititation: implications for quitting. Health Rep 9: 39-46.

Chow FA, Seidler FJ, McCook EC, Slotkin TA (2000). Adolescent nicotine exposure alters cardiac autonomic responsiveness: $\beta$-adrenergic and $\mathrm{m} 2$-muscarinic receptors and their linkage to adenylyl cyclase. Brain Res 878: 119-126.

Colby SM, Tiffany ST, Shiffman S, Niaura RS (2000). Are adolescent smokers dependent on nicotine? A review of the evidence. Drug Alcohol Depend 59: S83-S95.

Cornelius MD, Leech SL, Goldschmidt L, Day NL (2000). Prenatal tobacco exposure: is it a risk factor for early tobacco experimentation? Nicotine Tobacco Res 2: 45-52. 
Cucchiaro G, Commons KG (2003). $\alpha-4$ Nicotinic acetylcholine receptor subunit links cholinergic to brainstem monoaminergic neurotransmission. Synapse 49: 195-205.

DiFranza JR, Wellman RJ (2005). A sensitization-homeostasis model of nicotine craving, withdrawal, and tolerance: integrating the clinical and basic science literature. Nicotine Tobacco Res 7: 9-26.

Duncan MJ, Short J, Wheeler DL (1999). Comparison of the effects of aging on $5-\mathrm{HT}_{7}$ and $5-\mathrm{HT}_{1 \mathrm{~A}}$ receptors in discrete regions of the circadian timing system in hamsters. Brain Res 829: 39-45.

Faraday MM, Elliott BM, Grunberg NE (2001). Adult $v s$ adolescent rats differ in biobehavioral responses to chronic nicotine administration. Pharmacol Biochem Behav 70: 475-489.

Faraday MM, Elliott BM, Phillips JM, Grunberg NE (2003). Adolescent and adult male rats differ in sensitivity to nicotine's activity effects. Pharmacol Biochem Behav 74: 917-931.

Fergusson DM, Woodward LJ, Horwood LJ (1998). Maternal smoking during pregnancy and psychiatric adjustment in late adolescence. Arch Gen Psychiat 55: 721-727.

Fujita M, Charney DS, Innis RB (2000). Imaging serotonergic neurotransmission in depression: hippocampal pathophysiology may mirror global brain alterations. Biol Psychiat 48: 801-812.

Goodman E, Capitman J (2000). Depressive symptoms and cigarette smoking among teens. Pediatrics 106: 748-755.

Hurt RD, Croghan GA, Beede SD, Wolter TD, Croghan IT, Patten CA (2000). Nicotine patch therapy in 101 adolescent smokers: efficacy, withdrawal symptom relief, and carbon monoxide and plasma cotinine levels. Arch Pediatr Adolesc Med 154: 31-37.

Isaac PF, Rand MJ (1972). Cigarette smoking and plasma levels of nicotine. Nature 236: 308-310.

Jacobsen LK, Krystal JH, Mencl WE, Westerveld M, Frost SJ, Pugh KR (2005). Effects of smoking and smoking abstinence on cognition in adolescent tobacco smokers. Biol Psychiat 57: $56-66$.

Jacobsen LK, Slotkin TA, Westerveld M, Mencl WE, Pugh KR (2006). Visuospatial memory deficits during nicotine withdrawal in adolescents with prenatal exposure to active maternal smoking. Neuropsychopharmacology, in press.

Jevtovic-Todorovic V, Hartman RE, Izumi Y, Benshoff ND, Dikranian K, Zorumski CF et al (2003). Early exposure to common anesthetic agents causes widespread neurodegeneration in the developing rat brain and persistent learning deficits. J Neurosci 23: 876-882.

Kandel DB, Wu P, Davies M (1994). Maternal smoking during pregnancy and smoking by adolescent daughters. Am J Public Health 84: 1407-1413.

Klein LC, Stine MM, Pfaff DW, Vandenbergh DJ (2003). Maternal nicotine exposure increases nicotine preference in periadolescent male but not female C57B1/6J mice. Nicotine Tobacco Res 5: 117-124.

Klein LC, Stine MM, Vandenbergh DJ, Whetzel CA, Kamens HM (2004). Sex differences in voluntary oral nicotine consumption by adolescent mice: a dose-response experiment. Pharmacol Biochem Behav 78: 13-25.

Kusserow H, Davies B, Hörtnagl H, Voigt I, Stroh T, Bert B et al (2004). Reduced anxiety-related behaviour in transgenic mice overexpressing serotonin-1A receptors. Mol Brain Res 129: $104-116$.

Levin ED (1999). Persisting effects of chronic adolescent nicotine administration on radial-arm maze learning and response to nicotinic challenges. Neurotoxicol Teratol 21: 338.

Levin ED, Slotkin TA (1998). Developmental neurotoxicity of nicotine. In: Slikker W, Chang LW (eds). Handbook of Developmental Neurotoxicology. Academic Press: San Diego. pp 587-615.

Levin ED, Uemura E, Bowman RE (1991). Neurobehavioral toxicology of halothane in rats. Neurotoxicol Teratol 13: $461-470$
Leysen JE, Niemegeers CJ, Van Nueten JM, Laduron PM (1982). ${ }^{3}[\mathrm{H}]$ Ketanserin (R41468), a selective ${ }^{3} \mathrm{H}$-ligand for serotonin ${ }_{2}$ receptor binding sites: binding properties, brain distribution, and functional role. Mol Pharmacol 21: 301-314.

Lichtensteiger W, Ribary U, Schlumpf M, Odermatt B, Widmer HR (1988). Prenatal adverse effects of nicotine on the developing brain. Prog Brain Res 73: 137-157.

Lichtensteiger W, Schlumpf M (1985). Prenatal nicotine affects fetal testosterone and sexual dimorphism of saccharin preference. Pharmacol Biochem Behav 23: 439-444.

Luck W, Nau H, Hansen R, Steldinger R (1985). Extent of nicotine and cotinine transfer to the human fetus, placenta and amniotic fluid of smoking mothers. Dev Pharmacol Ther 8: 384-395.

Maes M, Meltzer H (1995). The serotonin hypothesis of major depression. In: Bloom FE, Kupfer DJ, Bunney BS, Ciaranello RD, Davis KL, Koob GF et al (eds). Psychopharmacology: The Fourth Generation of Progress. Raven Press: New York. pp 933-944.

Martini S, Wagner FA, Anthony JC (2002). The association of tobacco smoking and depression in adolescence: evidence from the United States. Subst Use Misuse 37: 1853-1867.

Meyer A, Seidler FJ, Aldridge JE, Tate CA, Cousins MM, Slotkin TA (2004a). Critical periods for chlorpyrifos-induced developmental neurotoxicity: alterations in adenylyl cyclase signaling in adult rat brain regions after gestational or neonatal exposure. Environ Health Perspect 112: 295-301.

Meyer A, Seidler FJ, Cousins MM, Slotkin TA (2003). Developmental neurotoxicity elicited by gestational exposure to chlorpyrifos: when is adenylyl cyclase a target? Environ Health Perspect 111: 1871-1876.

Meyer A, Seidler FJ, Slotkin TA (2004b). Developmental effects of chlorpyrifos extend beyond neurotoxicity: critical periods for immediate and delayed-onset effects on cardiac and hepatic cell signaling. Environ Health Perspect 112: 170-178.

Morin D, Sapena R, Zini R, Tillement JP (1992). Serotonin enhances the $\beta$-adrenergic response in rat brain cortical slices. Eur J Pharmacol 225: 273-274.

Murrin LC, Ferrer JR, Zeng W (1985). Nicotine administration during pregnancy and its effect on striatal development. Neurosci Abs 11: 69.

Nelson DE, Giovino GA, Shopland DR, Mowery PD, Mills SL, Eriksen MP (1995). Trends in cigarette smoking among US adolescents, 1974 through 1991. Am J Public Health 85: 34-40.

Nestler EJ (1992). Molecular mechanisms of drug addiction. J Neurosci 12: 2439-2450.

Niaura R, Bock B, Lloyd EE, Brown R, Lipsitt LP, Buka S (2001). Maternal transmission of nicotine dependence: psychiatric, neurocognitive and prenatal factors. Am J Addict 10: 16-29.

Olanow CW, Arendash GW (1994). Metals and free radicals in neurodegeneration. Curr Opin Neurol 7: 548-558.

Oncken C, McKee S, Krishnan-Sarin S, O'Malley S, Mazure C (2004). Gender effects of reported in utero tobacco exposure on smoking initiation, progression and nicotine dependence in adult offspring. Nicotine Tobacco Res 6: 829-833.

Park S, Harrold JA, Widdowson PS, Williams G (1999). Increased binding at $5-\mathrm{HT}_{1 \mathrm{~A}}, 5-\mathrm{HT}_{1 \mathrm{~B}}$, and $5-\mathrm{HT}_{2 \mathrm{~A}}$ receptors and $5-\mathrm{HT}$ transporters in diet-induced obese rats. Brain Res 847: 90-97.

Patten CA, Choi WS, Gillin JC, Pierce JP (2000). Depressive symptoms and cigarette smoking predict development and persistence of sleep problems in US adolescents. Pediatrics 106: 50-58.

Pauly JR, Sparks JA, Hauser KF, Pauly TH (2004). In utero nicotine exposure causes persistent, gender-dependant changes in locomotor activity and sensitivity to nicotine in $\mathrm{C} 57 \mathrm{Bl} / 6$ mice. Intl J Dev Neurosci 22: 329-337.

Pierce JP, Gilpin E (1996). How long will today's new adolescent smoker be addicted to cigarettes? Am J Pub Health 86: 253-256.

Qiao D, Seidler FJ, Slotkin TA (2005). Oxidative mechanisms contributing to the developmental neurotoxicity of nicotine and chlorpyrifos. Toxicol Appl Pharmacol 206: 17-26. 
Rao TS, Correa LD, Adams P, Santori EM, Sacaan AI (2003). Pharmacological characterization of dopamine, norepinephrine and serotonin release in the rat prefrontal cortex by neuronal nicotinic acetylcholine receptor agonists. Brain Res 990: 203-208.

Raymond JR, Mukhin YV, Gettys TW, Garnovskaya MN (1999). The recombinant $5-\mathrm{HT}_{1 \mathrm{~A}}$ receptor: $\mathrm{G}$ protein coupling and signalling pathways. Br J Pharmacol 127: 1751-1764.

Ribary U, Lichtensteiger W (1989). Effects of acute and chronic prenatal nicotine treatment on central catecholamine systems of male and female rat fetuses and offspring. J Pharmacol Exp Ther 248: 786-792.

Rovescalli AC, Brunello N, Perez J, Vitali S, Steardo L, Racagni G (1993). Heterologous sensitization of adenylate cyclase activity by serotonin in the rat cerebral cortex. Eur Neuropsychopharmacol 3: 463-475.

Salin-Pascual RJ, De la Fuente JR, Galicia-Polo L, Drucker-Colin R (1995). Effects of transdermal nicotine on mood and sleep in nonsmoking major depressed patients. Psychopharmacology 121 476-479.

Sarasin A, Schlumpf M, Müller M, Fleischmann I, Lauber ME, Lichtensteiger W (2003). Adrenal-mediated rather than direct effects of nicotine as a basis of altered sex steroid synthesis in fetal and neonatal rat. Reprod Toxicol 17: 153-162.

Segarra AC, Strand FL (1989). Perinatal administration of nicotine alters subsequent sexual behavior and testosterone levels of male rats. Brain Res 480: 151-159.

Seidler FJ, Levin ED, Lappi SE, Slotkin TA (1992). Fetal nicotine exposure ablates the ability of postnatal nicotine challenge to release norepinephrine from rat brain regions. Dev Brain Res 69: 288-291.

Seth P, Cheeta S, Tucci S, File SE (2002). Nicotinic-serotonergic interactions in brain and behaviour. Pharmacol Biochem Behav 71: 795-805.

Shimohama S, Greenwald DL, Shafron DH, Akaika A, Maeda T, Kaneko $S$ et al (1998). Nicotinic $\alpha 7$ receptors protect against glutamate neurotoxicity and neuronal ischemic damage. Brain Res 779: 359-363.

Slotkin TA (1992). Prenatal exposure to nicotine: What can we learn from animal models?. In: Zagon IS, Slotkin TA (eds). Maternal Substance Abuse and the Developing Nervous System. Academic Press: San Diego. pp 97-124.

Slotkin TA (1998). Fetal nicotine or cocaine exposure: which one is worse? J Pharmacol Exp Ther 285: 931-945.

Slotkin TA (1999). Developmental cholinotoxicants: nicotine and chlorpyrifos. Environ Health Perspect 107: 71-80.

Slotkin TA (2002). Nicotine and the adolescent brain: insights from an animal model. Neurotoxicol Teratol 24: 369-384.

Slotkin TA (2004). Cholinergic systems in brain development and disruption by neurotoxicants: nicotine, environmental tobacco smoke, organophosphates. Toxicol Appl Pharmacol 198: 132-151.

Slotkin TA, Auman JT, Seidler FJ (2003). Ontogenesis of $\beta$ adrenoceptor signaling: implications for perinatal physiology and for fetal effects of tocolytic drugs. J Pharmacol Exp Ther 306: $1-7$.

Slotkin TA, Cousins MM, Seidler FJ (2004). Administration of nicotine to adolescent rats evokes regionally selective upregulation of CNS $\alpha 7$ nicotinic acetylcholine receptors. Brain Res 1030: 159-163.

Slotkin TA, Epps TA, Stenger ML, Sawyer KJ, Seidler FJ (1999). Cholinergic receptors in heart and brainstem of rats exposed to nicotine during development: implications for hypoxia tolerance and perinatal mortality. Dev Brain Res 113: 1-12.

Slotkin TA, Orband-Miller L, Queen KL, Whitmore WL, Seidler FJ (1987). Effects of prenatal nicotine exposure on biochemical development of rat brain regions: maternal drug infusions via osmotic minipumps. J Pharmacol Exp Ther 240: 602-611.
Slotkin TA, Tate CA, Cousins MM, Seidler FJ (2002). Functional alterations in CNS catecholamine systems in adolescence and adulthood after neonatal chlorpyrifos exposure. Dev Brain Res 133: $163-173$.

Smith PK, Krohn RI, Hermanson GT, Mallia AK, Gartner FH, Provenzano MD et al (1985). Measurement of protein using bicinchoninic acid. Anal Biochem 150: 76-85.

Snedecor GW, Cochran WG (1967). Statistical Methods. Iowa State University Press: Ames, Iowa. 593pp.

Spear LP (2000). The adolescent brain and age-related behavioral manifestations. Neurosci Biobehav Rev 24: 417-463.

Stockmeier CA, Shapiro LA, Dilley GE, Kolli TN, Friedman L, Rajkowska G (1998). Increase in serotonin-1A autoreceptors in the midbrain of suicide victims with major depression: postmortem evidence for decreased serotonin activity. J Neurosci 18: 7394-7401.

Tizabi Y, Popke EJ, Rahman MA, Nespor SM, Grunberg NE (1997). Hyperactivity induced by prenatal nicotine exposure is associated with an increase in cortical nicotinic receptors. Pharmacol Biochem Behav 58: 141-146.

Trauth JA, McCook EC, Seidler FJ, Slotkin TA (2000a). Modeling adolescent nicotine exposure: effects on cholinergic systems in rat brain regions. Brain Res 873: 18-25.

Trauth JA, Seidler FJ, Ali SF, Slotkin TA (2001). Adolescent nicotine exposure produces immediate and long-term changes in CNS noradrenergic and dopaminergic function. Brain Res 892: 269-280.

Trauth JA, Seidler FJ, McCook EC, Slotkin TA (1999). Adolescent nicotine exposure causes persistent upregulation of nicotinic cholinergic receptors in rat brain regions. Brain Res 851: 9-19.

Trauth JA, Seidler FJ, Slotkin TA (2000b). An animal model of adolescent nicotine exposure: effects on gene expression and macromolecular constituents in rat brain regions. Brain Res 867: 29-39.

Trauth JA, Seidler FJ, Slotkin TA (2000c). Persistent and delayed behavioral changes after nicotine treatment in adolescent rats. Brain Res 880: 167-172.

Tsoh JY, Humfleet GL, Munoz RF, Reus VI, Hartz DT, Hall SM (2000). Development of major depression after treatment for smoking cessation. Am J Psychiat 157: 368-374.

Tzavara ET, Monory K, Hanoune J, Nomikos GG (2002). Nicotine withdrawal syndrome: behavioural distress and selective upregulation of the cyclic AMP pathway in the amygdala. Eur $J$ Neurosci 16: 149-153.

Wakschlag LS, Hans SL (2002). Maternal smoking during pregnancy and conduct problems in high-risk youth: a developmental framework. Dev Psychopathol 14: 351-369.

Wakschlag LS, Lahey BB, Loeber R, Green SM, Gordon RA, Leventhal BL (1997). Maternal smoking during pregnancy and the risk of conduct disorder in boys. Arch Gen Psychiat 54: 670-676.

Wu LT, Anthony JC (1999). Tobacco smoking and depressed mood in late childhood and early adolescence. Am J Public Health 89: $1837-1840$.

Xu Z, Seidler FJ, Ali SF, Slikker W, Slotkin TA (2001). Fetal and adolescent nicotine administration: effects on CNS serotonergic systems. Brain Res 914: 166-178.

Xu Z, Seidler FJ, Cousins MM, Slikker W, Slotkin TA (2002). Adolescent nicotine administration alters serotonin receptors and cell signaling mediated through adenylyl cyclase. Brain Res 951: 280-292.

Xu Z, Seidler FJ, Tate CA, Garcia SJ, Slikker W, Slotkin TA (2003). Sex-selective hippocampal alterations after adolescent nicotine administration: effects on neurospecific proteins. Nicotine Tobacco Res 5: 955-960.

Yatham LN, Liddle PF, Dennie J, Shiah IS, Adam MJ, Lane CJ et al (1999). Decrease in brain serotonin-2 receptor binding in patients with major depression following desipramine treatment: 
a positron emission tomography study with fluorine-18-labeled setoperone. Arch Gen Psychiat 56: 705-711.

Yatham LN, Liddle PF, Shiah IS, Scarrow G, Lam RW, Adam MJ et al (2000). Brain serotonin-2 receptors in major depression: a positron emission tomography study. Arch Gen Psychiat 57: 850-858. Zahalka EA, Seidler FJ, Lappi SE, McCook EC, Yanai J, Slotkin TA (1992). Deficits in development of central cholinergic pathways caused by fetal nicotine exposure: differential effects on choline acetyltransferase activity and $\left[{ }^{3} \mathrm{H}\right]$ hemicholinium-3 binding. Neurotoxicol Teratol 14: 375-382.

Zeiders JL, Seidler FJ, Slotkin TA (1999). Agonist-induced sensitization of $\beta$-adrenoceptor signaling in neonatal rat heart: expression and catalytic activity of adenylyl cyclase. J Pharmacol Exp Ther 291: 503-510. 